\title{
B2C — bubble to cluster: the dot-com boom, spin-off entrepreneurship, and regional agglomeration
}

\author{
Guido Buenstorf • Dirk Fornahl
}

Published online: 16 September 2008

(C) The Author(s) 2008. This article is published with open access at Springerlink.com

\begin{abstract}
This article studies entrepreneurial activities emerging out of one of Germany's most prominent dot-com firms, Intershop, a maker of e-commerce software. We show that Intershop spawned about 40 new ventures. Most spin-offs entered locally, giving rise to a small but growing software cluster and counteracting the job losses that accompanied the parent firm's drastic downsizing after 2000. We trace the knowledge transfer from Intershop to the spin-offs and relate it to recent theorizing on the spin-off process as well as spin-off-based cluster formation. The Intershop case suggests that temporarily successful dot-coms could exert lasting effects on regional development.
\end{abstract}

Keywords Spin-offs • Serial entrepreneurship • Industry agglomeration • E-commerce $\cdot$ Software industry

JEL Classification $\mathrm{L} 26 \cdot \mathrm{L} 86 \cdot \mathrm{M} 13 \cdot \mathrm{R} 30$

We are grateful to Thomas Baumann, Mario Habekost, Anja Klaukien, Steven Klepper, Max-Peter Menzel, Paul Nightingale, and Hagen Worch for helpful comments and discussions. All errors are ours.

G. Buenstorf $(\bowtie)$

Evolutionary Economics Group, Max Planck Institute of Economics,

Kahlaische Strasse 10, 07745 Jena, Germany

e-mail: buenstorf@econ.mpg.de

D. Fornahl

Institute for Economic Policy Research, Universität Karlsruhe (TH),

Kaiserstrasse 12, 76128 Karlsruhe, Germany

e-mail: fornahl@iww.uni-karlsruhe.de 


\section{Introduction}

Assessments of the 1990s dot-com boom have shifted between two extremes. Before the stock markets crashed in 2000-2001, there was widespread enthusiasm about the "new economy," often including the belief that fundamental economic principles were no longer valid in the Internet age. After the collapse, the enthusiasm rapidly gave way to a new conventional wisdom holding that the "new economy" had been based on an unfortunate coincidence of greed, hubris and naïveté, producing little that was of lasting substance. From the investor's perspective, the latter assessment is indeed straightforward, given the large amounts of money lost, as well as the fact that many of the dot-com firms have folded altogether.

This article explores the possibility that dot-com firms had substantial, lasting effects that were not reflected in the investor's portfolio. We take our motivation for this study from two strands of literature. First, in the literature on serial entrepreneurship, it has been suggested that analyzing individual ventures in isolation may be insufficient to evaluate the importance of entrepreneurship, as it neglects potentially beneficial effects of entrepreneurial experience on the performance of later ventures started by the same entrepreneur (Westhead and Wright 1998; Sarasvathy and Menon 2004). Second, recent empirical studies indicate that individual firms can trigger cluster formation by providing a seedbed for subsequent spin-off entry, which tends to be concentrated locally. Examples include Fairchild Semiconductors in Silicon Valley (Moore and Davis 2004; Klepper 2008), SP Radio in the Danish telecommunications cluster (Dahl et al. 2003), and B.F. Goodrich's role in the emergence of Akron, Ohio, as the center of the U.S. tire industry (Buenstorf and Klepper 2008). Can we observe similar dynamics in regions that were home to (temporarily) successful dot-com firms?

To answer this question, we focus on learning processes within firms. Previous research on spin-offs has highlighted the role of incumbent firms as (involuntary) training grounds for employees (Garvin 1983; Agarwal et al. 2004; Klepper and Sleeper 2005). However, little is known about what exactly spin-off founders have learned in their previous employments and what kinds of knowledge transfer underlie the often exceptional performance of spinoffs. Also, the interrelations between the regional spin-off process and other processes affecting cluster dynamics, such as regional network dynamics, the provision of entrepreneurial role models (Fornahl 2003), and non-spin-off entry (see, e.g., Bresnahan et al. 2001; Feldman 2001), have been largely unexplored.

In this article, we begin to pursue these issues in an explorative case study. We trace the regional legacy of one of Germany's most prominent protagonists of the dot-com boom, Intershop Communications, the Jena-based maker of e-commerce software for providers of online shops. Intershop was a global pioneer of e-commerce software development that grew rapidly during the boom. It subsequently encountered severe difficulties, losing money throughout almost all its corporate lifespan. As with other fallen dot-com stars, today's 
conventional wisdom has it that Intershop was an unequivocal failure. The firm has been singled out as the biggest annihilator of investor money by the German association of private investors (Deutsche Schutzvereinigung für Wertpapierbesitz 2006). According to their estimates, Intershop stock valued Euro 10,000 at the end of 2000 had a value of Euro 27 at the end of 2005. Intershop has survived to date, but was forced to downsize drastically its operations. Only most recently, its financial situation and employment numbers seem to have stabilized.

We suggest below that Intershop's temporary success allowed the firm to make a lasting contribution to its home region. Intershop's growth opened a new trajectory for local development based on software and web-based services rather than the traditional local industries, most notably optics and instrument-making. Its subsequent decline was accompanied by new entrepreneurial activities initiated both by Intershop's founding team and by employees leaving the firm. Through creating new employment opportunities and keeping human capital in the region, the spin-offs helped to sustain the favorable regional dynamics initiated by the parent firm. Based on extensive interviews, our empirical analysis allows us to identify the main channels through which Intershop enabled these subsequent activities. Our results provide new insights into employee learning as a basis of spin-off activities, and also into the links between the spin-off process and other aspects of regional industrial dynamics, including labor pooling and regional cooperation. In addition to presenting specific findings for the Intershop case, the study thus suggests new directions for future quantitative work.

The remainder of the article is organized as follows. Section 2 provides the theoretical background of the analysis by summarizing prior work on spin-off formation as well as the role of spin-offs in the evolution of industry agglomerations. Section 3 outlines the empirical approach of the study. Section 4 presents our narrative on the growth and subsequent decline of Intershop. Section 5 turns to the entrepreneurial activities by Intershop's founding team that accompanied the firm's downsizing. Section 6 discusses the spin-off activities of other Intershop employees. It also relates the manner in which a local support structure for nascent software entrepreneurs developed with Intershop's support. Section 7 studies additional regional effects of Intershop's development. Section 8 discusses the implications of the case study for the emerging literature on spin-offs and spin-off-based clustering. Section 9 concludes.

\section{Theoretical background}

Spin-offs (i.e., startups organized by former employees of firms active in the same industry) have recently been the object of intense scholarly attention. In this section, we summarize prior findings on the spin-off process and the role of spin-offs in regional cluster formation. The emergence of spin-offs is then 
related to the notion of Marshallian agglomeration economies associated with the regional clustering of industries.

\subsection{The emergence of spin-offs}

Spin-offs are a distinctive subset of entrepreneurial startups. Empirical research has identified a number of regularities in the spin-off process and in spin-off characteristics. Studies of different industries (e.g., Klepper 2002; Agarwal et al. 2004; Klepper and Sleeper 2005) found that, on average, spinoffs outperformed other de novo entrants. This suggests that building on knowledge they acquired while working for the parent firm, spin-off founders bestow capabilities on their ventures in ways that other founders do not. Recent work has also found spin-off success to be related to the duration that spin-off founders were employed at the parent firm, and to the kind of jobs they held (Dahl and Reichstein 2006). Time requirements of on-the-job learning, as well as superior learning opportunities faced by individuals in higher-level positions, can account for these results.

In addition to enabling the acquisition of knowledge, prior industry experience also affects whether a business opportunity is discovered and how it is framed (Shane 2000). Klepper and Sleeper (2005) show for the U.S. laser industry that spin-offs tended to enter into markets that were closely related to those served by their parent firms. These authors also find that spin-offs drew on specific knowledge their founders accumulated on their prior job rather than on more general business experience. Buenstorf (2007a) finds similar patterns in the German laser industry.

While on-the-job-learning enables employees to discover entrepreneurial opportunities and exploit them through spin-off companies, the empirical evidence suggests that actual spin-off formation is frequently related to events in the parent firm, such as changes in leadership and mergers or acquisitions (Brittain and Freeman 1986; Eriksson and Kuhn 2006). Such events often induce strategy conflicts (Klepper and Thompson 2006) and/or lead to disruptions in the individual employee's working environment. In analogy to a distinction often made in the entrepreneurship literature, spin-offs can thus be subdivided into two categories. "Opportunity spin-offs" are driven by newly identified entrepreneurial opportunities, whereas "necessity spin-offs" are triggered by external events that render continued employment in the existing firm less attractive, thus reducing the (perceived) opportunity costs of entrepreneurial activities (Buenstorf 2007b).

Research linking the characteristics of parent firms and spin-offs further corroborates the conjecture that knowledge is transferred in the spin-off process. First, the performance of spin-offs is positively related to that of their parents, i.e. success breeds success in the spin-off process (Klepper 2002). Second, better-performing incumbent firms are generally more "fertile" as breeding grounds of spin-offs. The latter result has been further refined by Agarwal et al. (2004) who distinguish between the potential and the actual number of spin-offs. They suggest that, while the number of potential spin-offs 
increases with the capabilities of a firm, the actual number of spin-offs is greatest when a capable firm generates new business opportunities without exploiting them itself.

\subsection{Spin-off-based cluster formation}

Recent empirical work on regional agglomerations shows that spin-offs play a crucial role in the formation of industry clusters. This was found for industries as diverse as the semiconductor industry (Moore and Davis 2004; Klepper 2008), the U.S. automobile industry (Klepper 2007), the U.S. tire industry (Buenstorf and Klepper 2008) and the Italian plastics district of Correggio (Patrucco 2005). ${ }^{1}$ Spin-offs predominantly enter at or close to the location of their parent firm. In this way, new entrants develop endogenously within the region, and their capabilities derive from those of the parent firms. As a consequence, more and better entrants can be expected in regions with more and better incumbents in the industry.

Due to the self-reinforcing "success breeds success" dynamics of the spinoff process, historical singularities such as the chance location of one or several successful early entrants in a region can give rise to long-run effects on regional development. The nature and orientation of early entrants in a region thus shapes the region's further technological development path. Given the crucial role of critical mass and hysteresis effects implied by dynamic models of cluster formation (Brenner 2004), it is, moreover, conceivable that entrants can trigger lasting regional developments even when they are only temporarily successful themselves.

\subsection{Spin-offs and regional external economies}

The intra-regional transfer of organizational capabilities through the spin-off process informs a theoretical account of cluster formation that does not depend on the presence of external economies stemming from traditional Marshallian agglomeration economies (Buenstorf and Klepper 2006). However, potential interrelations between the spin-off process and other dynamic processes of cluster evolution are largely unexplored. Such interrelations may be relevant along two dimensions.

First, successful early entrants in a region may not only be fertile breeding grounds of spin-offs. Their growth may also give rise to positive external effects on regional development that are not restricted to spin-offs. Potential benefits accruing from these externalities operate through a variety of channels. For example, successful firms add to the supply of human capital by attracting

\footnotetext{
${ }^{1}$ A variant of the spin-off-based model of cluster formation was observed in Cambridge (U.K.), where spin-offs from technical consultancies, often becoming involved in product design and the commercialization of new technologies, have gained in importance relative to university spin-offs (Lawson 2003).
} 
skilled employees to the region and enabling employees to accumulate knowledge on their jobs, thus enhancing the regional knowledge base (Fornahl 2007). Prior work on industrial clustering has also highlighted the impact of new and growing firms on regional cooperation, customer-supplier relations, regional value chains, as well as the orientation of the regional universities and public research organizations (Lundvall 1988; Audretsch and Feldman 1996; Gray et al. 1996). Yet further effects may operate in a more indirect, cognitively mediated fashion. Successful entrepreneurial activities provide positive role models in the region, thus affecting other agents' attitudes toward entrepreneurship, their ability to discover entrepreneurial opportunities, and their willingness to start firms themselves. In this way, cognitive factors may help to explain regional differences both in the extent and the nature of entrepreneurial activities (Fornahl 2003; Sørensen and Sorenson 2003).

Second, the spin-off process itself may be strongly intertwined with the emergence of Marshallian agglomeration economies. Based on a case study of an Italian manufacturing district, Patrucco (2005) suggests that local spin-offs drove the regional diffusion of knowledge and the emergence of a common knowledge base. The highly specialized spin-offs created opportunities for high rates of vertical disintegration through sub-contracting. The spin-off process can likewise be expected to enhance the potential for labor pooling in a region, as it increases the number of potential employers active in the same industry, which makes the region more attractive for specialized workers. Personal contacts between spin-off founders sharing a prior employment in the same firm are, moreover, a potential source of regional social networks, which have been identified as important channels to access resources crucial for starting and operating a firm successfully (Sorenson 2003).

\section{Approach and data}

The general methodology adopted below is that of an explorative case study (Eisenhardt 1989). As is typical for this approach, we draw on a variety of kinds and sources of data, in particular interviews, survey methods and archival material. Our empirical research builds on an earlier project that focused on regional determinants of entrepreneurial activities in Jena (Fornahl 2007). As part of that project, which did not specifically target software firms, 24 interviews with local experts, managers and entrepreneurs were conducted. Additionally, a postal survey of 93 regional firms was performed.

For the present project, we initiated a new wave of empirical research activities in 2005/2006. We began by collecting publicly available material on the development of Intershop. Given our interest in spin-off activities, a list of spin-off firms was generated next (cf. Tables 1 and 2). In compiling and updating ${ }^{2}$ this list, we relied on public resources such as media reports,

\footnotetext{
${ }^{2}$ The final list (cf. Tables 1 and 2) reflects the spin-off population as of 2007/2008.
} 


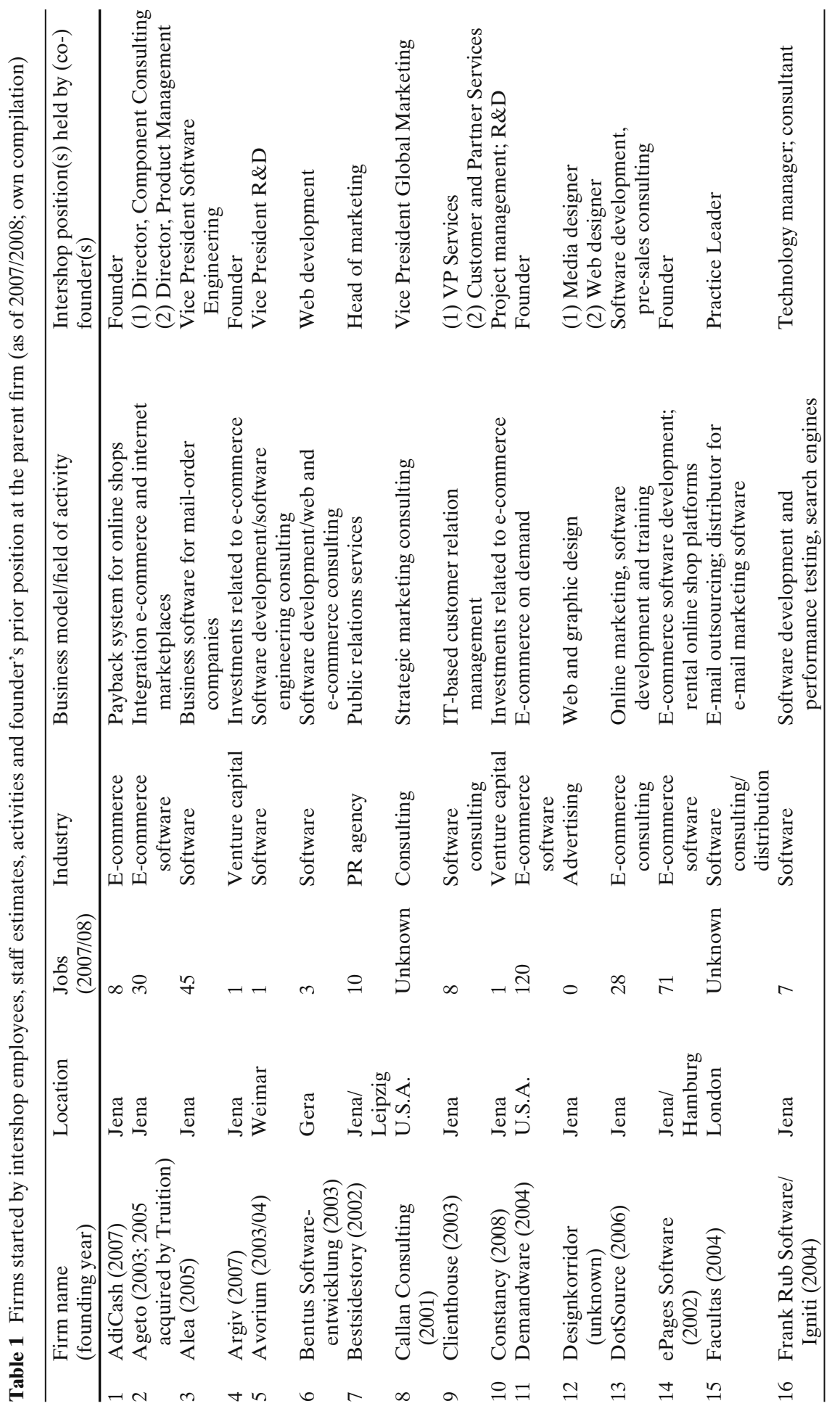




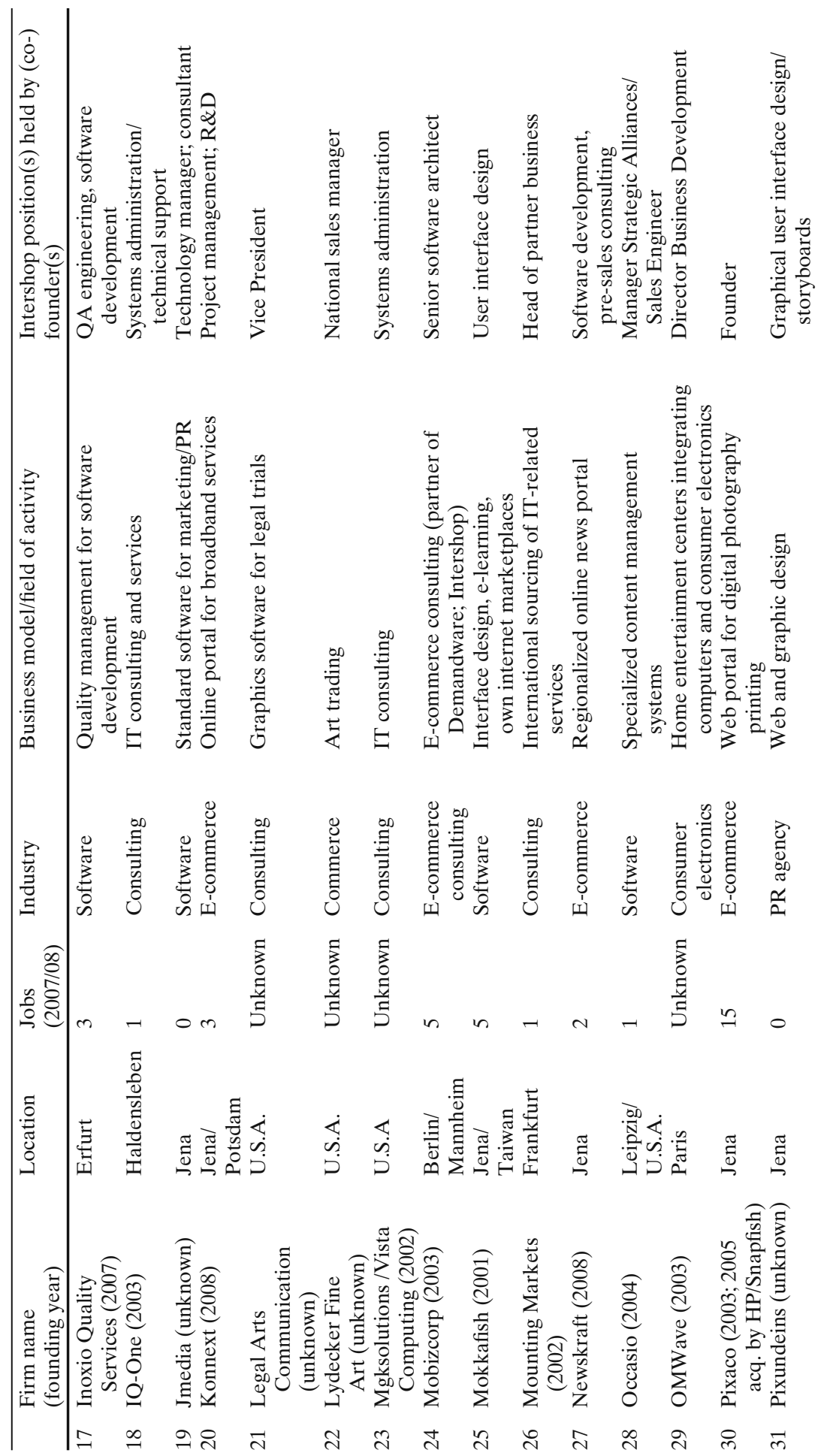




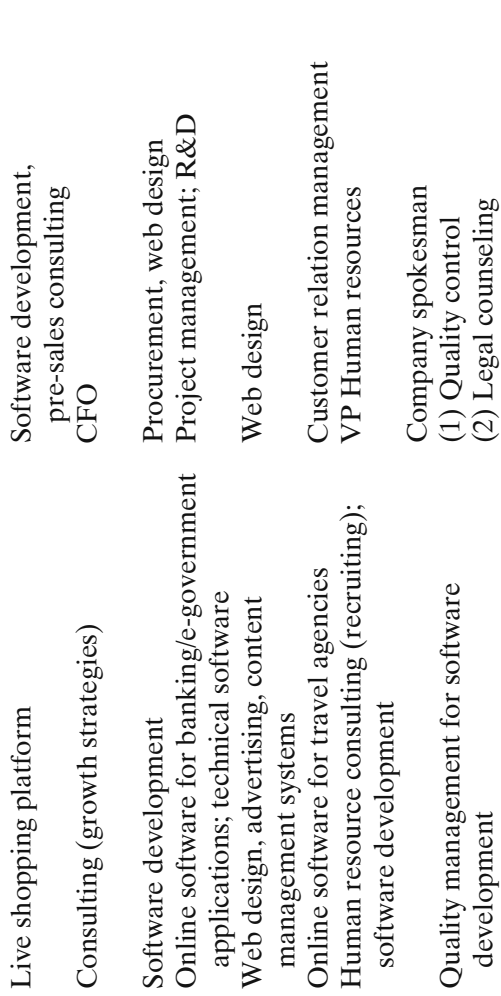

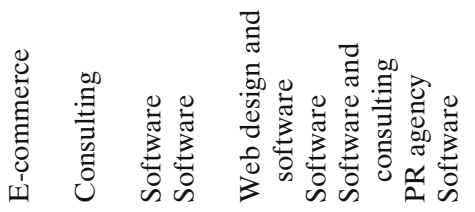

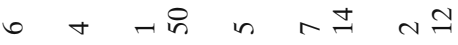

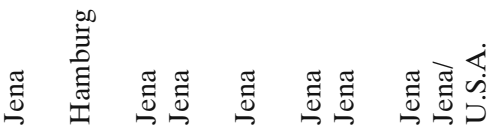

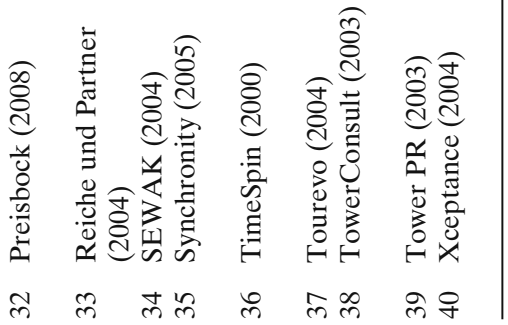




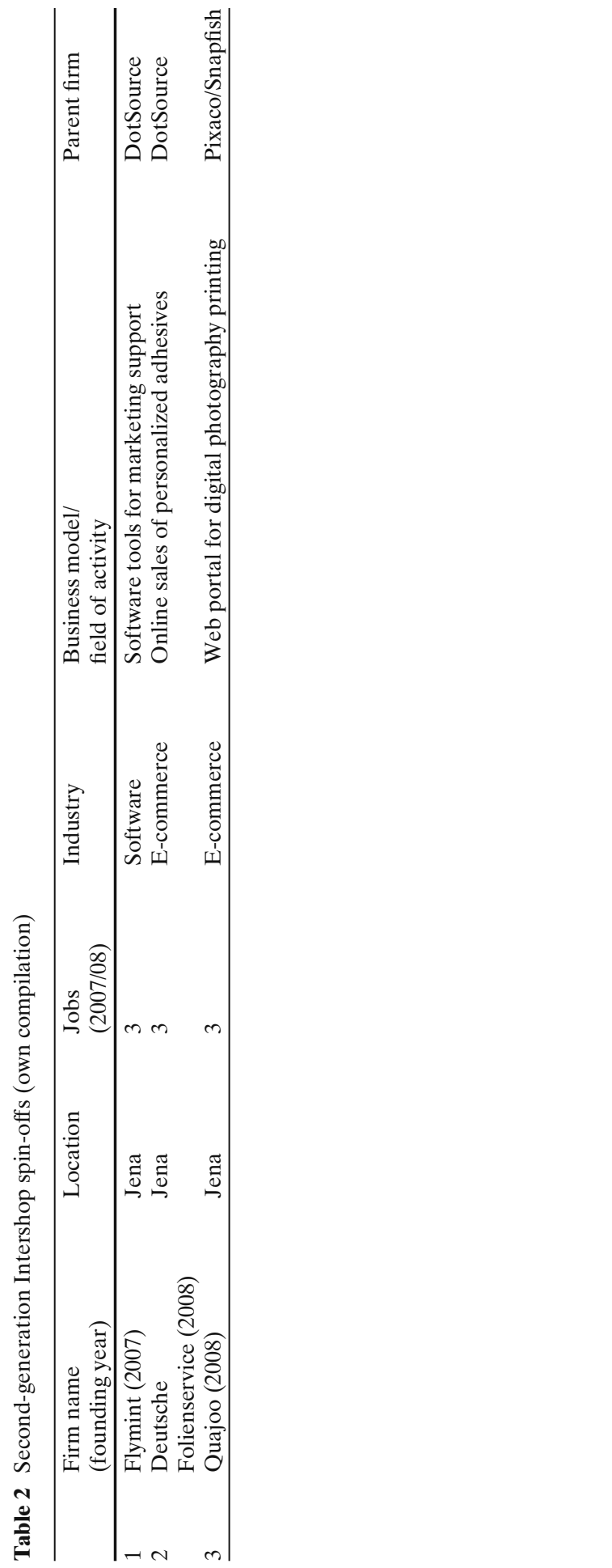


corporate web sites and online network platforms, which we complemented by information directly obtained from former Intershop employees.

Following the suggestions of Eisenhardt (1989), we then chose a strategic subset of spin-off founders and other local industry experts with whom we conducted extensive, semi-structured interviews. We primarily focused on the founders of spin-offs located in Jena, and made sure to exploit the whole spectrum of founder backgrounds and spin-off types (cf. Eisenhardt 1989, pp. 536-7). Specifically, our field research covered the new entrepreneurial activities of Intershop's founding team and the spin-offs organized by former members of the firm's top-tier management, but also several spin-off founders who held more marginal positions and had shorter employment spells at the parent firm. In total, 12 spin-off founders were interviewed, covering almost half the local spin-off population. The number of interviews allowed for substantial triangulation, enabling us to sort out general dimensions of the spin-off process from those aspects that only apply to specific cases or substantially differ between individual spin-off firms. To get a more encompassing view of the local industry, we conducted additional interviews with founders and managers of other local software firms, as well as with an academic computer scientist working for the local university. Further interviews were conducted in $2007 / 2008$ to trace new developments after the first round of interviews. The typical interview lasted $1-2 \mathrm{~h}$.

The focus on interviews with spin-off founders is in line with Schoenberger (1981), who points out that corporate interviews are particularly valuable in accounting for the situational complexity generally faced by decision makers in firms. Especially in contexts with changing organizational and regional structures or processes, interviews are a suitable research strategy to identify the driving forces underlying these dynamics. We utilized the interviews both to test causal relationships suggested in the existing literature and to develop new conjectures on the spin-off process and regional industrial dynamics. Our theory-building approach thus follows the iterative process described by Eisenhardt (1989).

\section{The rise and fall of Intershop}

Intershop Communications AG was a poster child of the German "new economy." Founded 2 years after German reunification in the formerly socialist East, the maker of e-commerce software for providers of online shops initially was an impressive success story that attained nationwide prominence. Since the end of the dot-com boom, Intershop has been struggling for survival. While laying off the majority of its workforce, it has lost large amounts of investor money.

Intershop was started in 1992 by Stephan Schambach, Karsten Schneider and Wilfried Beeck under the name NetConsult Communications GmbH. In the beginning, the firm primarily sold computer hardware and networks. Schambach had grown up in East Germany. Dropping out of his studies at the 
University of Jena, he started to sell home-assembled computers even before Germany was reunited (Virtel 2001). Schneider likewise was an East German native; he had worked as an electrical engineer with the local Carl Zeiss company. After the end of socialism, Schneider briefly ran a used-car business before joining a small computer firm. Finally, Beeck was a West German computer scientist who had accumulated substantial prior entrepreneurial experience before co-founding Intershop. Beeck had started his first software firm in 1983 and was distributing Steve Jobs's NeXt Computers when he joined forces with Schambach and Schneider to start Intershop.

Intershop's development into a producer of e-commerce software began in 1994 when, based on an idea by Schambach, the firm integrated its internal order processing system into the Internet (Berberich 1999). The firm subsequently specialized on web-related software development. In 1995, it introduced Intershop Online, the first standard software for e-commerce applications. One year later, Intershop was the first German software firm to attract VC funding (ibid.). It was thus able to grow rapidly. Intershop subsequently tried to attain market leadership in e-commerce software, a strategy that at the time convinced many growth-oriented analysts and investors. To be closer to the crucial U.S. market, it relocated its corporate headquarter to San Francisco.

In 1998 Intershop went public on the German Neuer Markt ${ }^{3}$ and subsequently also on NASDAQ. Its stock price skyrocketed (cf. Fig. 1). At one point, the firm had a market value of more than Euro 11.1 billion (March 10, 2000). Intershop's revenues increased from Euro 0.54 million in 1996 to nearly Euro 123 million in 2000, while its worldwide employment rose from 43 to 1,218 in the same period (cf. Table 3 ). The firm was widely regarded as a bluechip among the German "new economy" firms. In February 2000, the U.S. magazine Business Week ran a story on Intershop titled "Germany's Hot Star," which likened the Jena startup to Hewlett-Packard in its early days (Echikson 2000).

A crucial ingredient of Intershop's standing among analysts and investors was that, in contrast to many other German startups, it had early on focused on its presence in the U.S. market. During that time, Intershop claimed global leadership in the e-commerce market. Co-founder Stephan Schambach attained celebrity status as a successful German high-tech entrepreneur, and Intershop executives were sought-after experts to comment on policy discussions covering issues such as entrepreneurship, the Internet and even immigration policy. In 2000, the firm's local operations were moved to Jena's tallest building, a 150-m glass tower. Originally constructed as a socialist prestige project, this building was renamed Intershop Tower and remodeled into an office building custom-equipped for the needs of an IT firm.

\footnotetext{
${ }^{3}$ The Neuer Markt was a growth- and technology-oriented segment of the German Stock Exchange started in 1997 and closed down in 2003. Intershop was the first East German startup to be listed on the Neuer Markt.
} 
Fig. 1 Development of the intershop communications AG stock price (source: www.onvista.com)

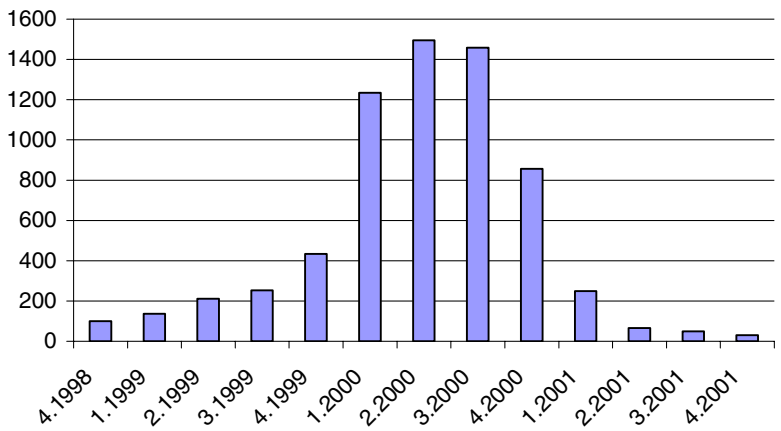

* The bars represent the average stock prices in that quarter of the year based on the stock prices on the first days of each month in the quarter.

Intershop's public image soon started to change. Beginning in April 2000, its stock price declined dramatically (cf. Fig. 1). On a single day early in 2001 the firm lost $70 \%$ of its stock market value. Lawsuits by frustrated investors and criminal prosecution ensued. In the following years, all three founders resigned from Intershop's active management. Beeck left Intershop in 2002, Schneider in 2003. Also in 2003 Schambach resigned as CEO. The position was taken over by then CFO Jürgen Schöttler, an economics $\mathrm{PhD}$ and experienced "old economy" executive (Klawitter 2003). Subsequently, Schambach retired from Intershop's management altogether and, as did his former co-founders, engaged in new entrepreneurial activities (see Section 5 below).

After the stock market crash, Intershop declined further. Revenues, R\&D investments and employment all decreased strongly from 2000 to 2006 (cf. Table 3). To save money, Intershop's corporate headquarter was moved back from San Francisco to Jena in 2002, and branch offices outside Europe and the U.S were shut down. A large number of employees were laid off or left the firm on their own initiative, with staff numbers falling to little more than 200 employees. Likewise, annual revenues decreased to below Euro 20 million 2004-2006. To date, the company has never been profitable on an annual basis.

Table 3 Intershop financial and employment data, 1996-2007 (not including media costs of online marketing; source: intershop communications AG, annual reports 1997-2007)

\begin{tabular}{lcccc}
\hline Year & $\begin{array}{l}\text { Revenue } \\
(€ \text { million })\end{array}$ & $\begin{array}{l}\text { Profit/loss } \\
(€ \text { million })\end{array}$ & $\begin{array}{l}\text { R\&D investment } \\
(€ \text { million })\end{array}$ & $\begin{array}{c}\text { Total } \\
\text { employment }\end{array}$ \\
\hline 1996 & 0.538 & -2.656 & 0.341 & 43 \\
1997 & 5.036 & -7.956 & 1.000 & 179 \\
1998 & 17.872 & -17.308 & 4.377 & 353 \\
1999 & 46.300 & -18.400 & 7.115 & 544 \\
2000 & 122.994 & -38.900 & 10.191 & 1,218 \\
2001 & 68.654 & -131.798 & 15.179 & 733 \\
2002 & 45.097 & -27.555 & 7.225 & 479 \\
2003 & 23.159 & -18.640 & 6.260 & 371 \\
2004 & 17.568 & -8.776 & 4.149 & 260 \\
2005 & 17.792 & -3.312 & 2.765 & 222 \\
2006 & 18.817 & -6.390 & 3.177 & 247 \\
2007 & 26.911 & -2.033 & 2.977 & 233 \\
\hline
\end{tabular}


A widespread assessment shared by our interview partners is that Intershop's software products were of high quality, while the firm had major management weaknesses, particularly in the marketing field. Moreover, in retrospect, Intershop's strategic orientation toward the high-end segment of the e-commerce software market has been criticized. Intershop's flagship product "Enfinity" may have been too complex for the IT capabilities of many potential customers (Von Bredow and Jung 2001).

While shrinking the firm to a sustainable size, Intershop's new management tried to safeguard the firm's future prospects by bringing in fresh capital as well as strengthening the marketing and sales divisions. Intershop's license revenues from existing customer accounts, which include names such as Hewlett Packard, Deutsche Telekom and Otto, are still substantial, but consulting services account for most of its income. The company has recently entered into two new lines of business: First, online marketing activities were commenced through the acquisition of SoQuero GmbH in 2006. Second, a new full service e-commerce business model allows customers to outsource their complete e-commerce activities including payments, logistics and the handling of returns. Most recently, Intershop's employment and sales seem to have stabilized. Positive earnings were reported in the first quarter of 2008.

\section{New entrepreneurial activities of Intershop's founding team}

As was indicated in the previous section, all three members of Intershop's founding team had prior entrepreneurial experience when they started Intershop. It was also noted above that all three left the firm's management after 2001. Since then, they have all engaged in renewed entrepreneurial activities.

Wilfried Beeck's departure from Intershop involved a fissioning of the firm. As part of its downsizing, Intershop had decided to focus its activities on the high-end Enfinity software, and to sell the rights in Intershop 4, which derived from the firm's original product and was targeted to SMEs and hosting providers. Beeck initially tried to find a buyer for Intershop 4. When these attempts failed, he was offered to take over Intershop 4 himself, as well as the existing customer accounts. Beeck then transferred the rights in Intershop 4 to a firm named ePages, which is the legal successor of an earlier firm he started back in the 1980s. EPages attracted a number of former Intershop employees, and in addition to the founder, two out of four top management team members had an Intershop background. While ePages has its headquarter and sales office in Beeck's home town, Hamburg, Jena is the location of its development activities with 44 local employees.

Beeck's departure from Intershop is indicative of a disagreement on strategy. His assessment of the market potential of Intershop 4 differed from that of the other owners who favored a concentration on the Enfinity software (Toparkus 2004). Notwithstanding its focus on smaller-sized customer firms, ePages continued to upgrade its product, for example by enabling its integration into Internet marketplaces such as eBay. In 2004, with ePages 5, an 
entirely new product was introduced. A major element of ePages' business is the development of software for online rental shops offered by hosting providers.

Pixaco was started by Karsten Schneider in 2003. Pixaco's business model was to provide a web portal allowing customers to upload digital image files for professional printing. The firm originated from the Bilderservice.de web portal, which was first started in 1999 by Creative Online Systems (later renamed into Vimago), an Intershop partner firm located in nearby Weimar, on the basis of Intershop's e-commerce software. Already before Pixaco was started, the digital photo processing facilities associated with Bilderservice.de were moved to the Intershop Tower in Jena. Given its heavy data traffic, the tower's sophisticated IT infrastructure was a major asset for Pixaco (Querengaesser 2004).

Former Vimago employees, including its software architect, joined Pixaco's initial management team. The new firm discontinued further development of the Bilderservice.de portal. Instead, it created a new, user-friendly portal to reach the end consumer market. In December 2005, Pixaco was acquired by Hewlett-Packard in a trade sale. Subsequently, it has been fully integrated into Snapfish, Hewlett-Packard's online photo service subsidiary.

Following the acquisition, Schneider became Snapfish's managing director, and the Pixaco facilities became Snapfish's headquarters for Continental Europe. In 2007 Schneider withdrew from Snapfish to engage in new entrepreneurial activities. He first started Argiv, a private investment firm targeting early-stage investments related to IT and web services. Later in the year, Schneider announced the formation of AdiCash, a VC-backed company developing a payback system for e-commerce transactions.

In contrast to the other two Intershop founders, Stephan Schambach started his new firm, Demandware, outside Jena and Germany. Demandware was organized in 2004 and located in the Boston region. Its business model is to combine e-commerce software development with on-demand software distribution (also known as software-as-a-service), which Schambach saw as the emerging dominant distribution model for business software. With on-demand software, customers do not install the program on their own computers, but rent computing time on the provider's computers. License fees are based on actual use rather than flat rates. Convinced of the new distribution model, Schambach initially attempted to change Intershop's strategic orientation toward the on-demand concept. Schambach suggests that he resorted to starting a new firm only when he could not implement the proposed changes to Intershop's business model because of massive resistance within the existing organization.

Demandware aspires to become the leading producer of on-demand ecommerce software and possibly also a leading platform for business software more generally. It is VC-backed and employs a number of former Intershop employees. Most notably, the firm hired Intershop's former chief software architect, Ulrike Mueller, who was leading the development of its Enfinity software. With currently 120 employees, Demandware is the largest of all new 
firms spawned by Intershop. Even though it located far from its roots, Demandware cooperates with Intershop spin-offs located in Jena, as well as with long-term Intershop partner Deutsche Telekom.

The new ventures of the Intershop founders were strongly influenced by their earlier experiences at Intershop. Both Beeck and Schambach remained active in Intershop's core market - development of e-commerce software with their new firms. Even though they focus on different market segments, both firms represent a competitive challenge to at least some of Intershop's business. The strategic differences between the two new firms are pronounced. EPages builds on Intershop's early success, keeping its software affordable for smaller-scale customers. The firm stresses its profitability rather than its growth potential. Its strategy is more conservative than that of Demandware, which, similar to Intershop in its early days, strives to pioneer a new software market that promises substantial opportunities for growth. With Demandware, Schambach moreover repeated Intershop's strategy of locating in the U.S., the global center of the e-commerce market.

Pixaco differed from the other firms in that it was not (primarily) a software developer but rather provided a web-based service. The Intershop impact on this firm is nonetheless discernible. Pixaco's web portal was based on Intershop software. Schneider's ability to grasp the opportunity presented by Bilderservice.de and to use it as the foundation of a new firm further reflects his Intershop experience. With Argiv, the discovery of opportunities has become the cornerstone of Schneider's activities. Finally, AdiCash pursues a novel business that, similar to Pixaco, combines e-commerce with a service that previously existed in traditional markets.

\section{Employee spin-offs and a self-organized technology park}

In addition to the new ventures started by Intershop's founding team, other firm members also engaged in entrepreneurial activities after leaving Intershop. While the origins of some spin-offs predate Intershop's problems, the firm's downsizing induced a number of its employees to start their own businesses, and spin-off activities were also encouraged by the Intershop management.

No complete listing of Intershop spin-offs exists. However, based on various online resources, local information, and personal communication, a minimum of 35 new firms started by former Intershop employees (in addition to the five firms discussed above) could be identified (cf. Table 1 for details). ${ }^{4}$ Eighteen of the 35 are spin-offs in the strict sense of having entered into software development and/or offering web-based services. Another nine firms provide consulting services, which is of little surprise given low barriers to entry in that

\footnotetext{
${ }^{4}$ This number does not include a number of ex-Intershop employees who work as free-lance software developers.
} 
industry. Further adding to the firms started by former Intershop employees, the first three "second-generation" spin-offs have recently been organized by spin-off employees who never worked for Intershop themselves (cf. Table 2).

\subsection{Employee learning and the business models of the spin-offs}

Only a single employee spin-off (Ageto, which subsequently became part of Canada-based Truition) entered in the same industry segment (i.e., e-commerce software development) that Intershop, as well as two of the founders' new firms (Demandware and ePages), are active in. Ageto/Truition concentrates on a specific kind of e-commerce software, enabling the integration of e-commerce activities and online auction platforms such as Ebay. In a similar way, most other spin-offs follow strategies that are related to e-commerce, but depart substantially from the parent firm's business model.

The business models of many spin-offs indicate these firms exploit specific knowledge that their founders gained at Intershop. Xceptance, co-founded by Intershop's former head of quality control and its legal advisor, develops and markets quality tests and automation techniques for software quality control. The founder of Mokkafish, which started by developing user interfaces, was in charge of interface design at Intershop. Similarly, J-media, which produced a standardized software supporting marketing and PR activities, was organized by a former member of Intershop's communication department. A direct connection between the jobs they held at Intershop and the focus of their new ventures can also be drawn for some of the employees who started consulting firms. For example, TowerConsult, the firm organized by Intershop's former director of human resources, offers recruiting services, whereas the former company spokesman started a PR agency. Likewise, one co-founder of Clienthouse, which concentrates on customer relation management consulting, was responsible for customer and partner services at Intershop.

Another clearly discernible aspect of the Intershop spin-offs is the ability of their founders to leverage contacts and to discover business opportunities related to software development and online services. Both Ageto/Truition and ePages are working to integrate e-commerce and online marketplaces. Alea, co-founded by Intershop's one-time chief software architect, Frank Gessner, develops integrated business software for mail-order firms. Its product is based on programs developed in an earlier firm of Gessner's co-founder (Clemens 2006). Alea is thus similar to Pixaco in adopting and further developing a business model that is related to Intershop's activities but had previously been developed outside the firm. The founder of Synchronity, which focuses on software for "e-government" applications (e-business solutions for the public sector), had held project management and software development jobs at Intershop before joining a public bank administering subsidized lending programs. Synchronity's initial product accordingly was a web-based solution for the administration of such programs.

Altogether, those members of Intershop who were most central to its strategic management developed the business models that are most closely related 
to that of the parent firm. Two of the firms started by Intershop's founders but only a single employee spin-off are developing e-commerce software that is at least in part competing with Intershop's own products. Moreover, comparing the business models pursued by firms started at different points in time, some differences can be noted. In particular, several of the most recent spin-offs are providers of online contents rather than upstream software developers such as Intershop and most of its early spin-offs.

The impression emerging from the business models - spin-offs entering in market segments and activities that reflect their founders' positions and projects at the parent firm - was reinforced by our interviews with spin-off founders. Interviewees frequently emphasized the continuity between their projects at Intershop and the subsequent spin-off activities, as well as the importance of specific skills acquired in their prior jobs. For example, one interviewed founder not only noted that he was still active in the same field of activity as in his time at Intershop, but that the same would also hold true for other spin-offs. Another founder characterized the software development expertise he had gained at Intershop as a "repertoire that I am still building upon."

This evidence for substantial employee learning enabling spin-off activities begs the question how Intershop was able to develop high-quality software in the first place. Its founders brought little prior expertise in software development. Likewise, many employees came without degrees in computer science (often dropping out from university for their job at Intershop), or even without any background in software development. Our interviewees suggested that Intershop's early entry into the e-commerce business, coupled with fortunate initial hiring decisions for key $R \& D$ positions, explains the firm's ability to develop its technological capabilities. Moreover, not all of the skills that future spin-off founders acquired at Intershop were related to software development. Rather, the importance of programming capabilities acquired at Intershop varied according to the position that the founder had occupied (and consequently the spin-offs' business models also differed).

Another dimension of learning was frequently stressed in the interviews: the importance of having gained work experience in a fast-growing, internationally active entrepreneurial firm. Besides lacking software-related expertise, many Intershop employees, including ones who later started spin-offs, joined the firm without any prior job experience. Our interviewees consistently emphasized the autonomy and room for experimentation that had characterized their Intershop jobs. Relatively junior employees handled large-scale projects and were delegated staff-supervision responsibilities. Also, working at Intershop often involved the management of international projects, an aspect that was particularly relevant for the majority of employees who had grown up in the isolation of pre-1990 socialist East Germany. In this way, Intershop's management practices and its corporate culture apparently were conducive to the later spin-off activities. 
In contrast, none of the interviewed spin-off founders confirmed that the role model provided by the Intershop founders had significantly affected their own decision to start a firm. A positive role model effect might have been expected in light of the prominence that Schambach and (to a lesser extent) the other founders had attained, and also the substantial wealth accumulated by them. Evidence of a role model effect was indeed found in an earlier study of entrepreneurial activities in Jena (Fornahl 2007; also see Section 7 below). It would moreover help to explain why so many Intershop employees became entrepreneurs, even though they had mostly been socialized in the anti-capitalist environment of pre-1990 East Germany.

It is conceivable that the negative answers were due to a role model effect that operated below the level of conscious reflection, so that our interviewees were not aware of its impact on their behavior. In this case, the importance of a role model effect cannot fully be evaluated. Another possibility is that, because most spin-off activities of Intershop employees took place after 2000, the Intershop founders had lost much of their attractiveness as role models. Some evidence furthermore suggests that Eastern Germany's socialist past had little constraining effect on the entrepreneurial activities coming out of Intershop. The younger Intershop employees had been teenagers in the post-reunification period when substantial entrepreneurial activities took place in the East as part of the transition to a market economy (Fritsch 2004). Some of the older employees who started spin-offs had engaged in entrepreneurial activities even before joining Intershop. More generally, during its rapid growth, Intershop had hired employees with rather diverse professional backgrounds. Their biographies often suggest they had not fully subscribed to socialist ideals.

In addition to the skills acquired through on-the-job learning, the entrepreneurial activities of ex-Intershop employees also benefited in a very direct way from the parent firm's temporary financial success. Even though we did not collect systematic data on the interviewees' personal wealth, several respondents acknowledged that money from trading Intershop stock had enabled their own spin-off activities, as well as those of other founders. In individual cases, supplier contracts with the parent firm were important to overcoming initial difficulties. Most of the spin-offs started out on a small scale and without VC backing. However, there were substantial cross-investments among the spin-off founders. These investment activities have become more explicit through the recent organization of investment firms such as Argiv, Constancy, and the TowerVenture cooperative (see below).

\subsection{Cooperation among the spin-offs}

Intershop played an active role in enabling the entrepreneurial activities of its former employees. When the firm began to lay off employees at a large scale, it utilized a German law allowing for publicly subsidized transfer firms. Under that law, the laid-off employees received a publicly funded transfer income 
(roughly corresponding to unemployment benefits), while Intershop had to cover both social insurance payments and re-training costs. Intershop's former director of human resources suggests that this institutional arrangement was more costly than the alternative of just laying off the respective employees, even including litigation and settlement costs that could be expected to arise in the latter case. Part of Intershop's motivation to incur these costs was to retain software competences in the region. From the beginning, it was expected that some of the employees shifted to the transfer firm would engage in entrepreneurial activities.

The transfer firm became the nucleus of the TowerByte cooperative of software firms organized late in 2003. TowerByte's members are start-ups engaged in various types of activities related to e-commerce. The cooperative currently has 28 member firms with an aggregate employment of 280. Fifteen member firms are Intershop spin-offs, but the cooperative also attracted startups the founders of which have no Intershop background. The individual firms focus on different submarkets and services. Accordingly, they are not directly competing with each other.

The TowerByte cooperative provides a number of services to its member firms. It rents office space in the Intershop Tower, which is occupied by the member firms. The firms are thus able to benefit from the building's IT and service infrastructure, as well as from the proximity to Intershop, ePages, Snapfish (which are all located in the Tower) and the other member firms. As a consequence of the available technological infrastructure and services, new firms can start small and quickly. In addition, the cooperative pools resources in the purchases of supplies and the provision of business services.

Since the TowerByte members differ in their specific competences, they are able to help each other by providing specific expertise, access to customers, and small-scale loans (Kalla 2005). Our interview partners from the cooperative stressed the role of information flows among the member firms. They also suggested that the proximity to other software firms makes it easier for member firms to hire new employees, since the availability of alternative employers significantly reduces the risk of joining a small startup. The larger size of the cooperation is also seen as a valuable signal of credibility to customers, enhancing their willingness to do business with the mostly small member firms. The TowerByte cooperative thus operates like a well-functioning, softwarespecific technology park. It is special, however, in that it is based on private initiative rather than public policy and receives only modest public subsidies.

As was acknowledged by our interview partners, the high degree of selfsufficiency is largely due to the low capitalization required to start a software firm. Capital was nonetheless identified as a potential bottleneck limiting the number and growth of software startups. Accordingly, building on the experience of the TowerByte cooperative, an investment cooperative named TowerVenture was organized in 2007 to support IT-related entrepreneurial ventures in the broader Jena region. The members of this cooperative are mostly founders of Intershop spin-offs. 


\section{Beyond spin-offs: Intershop's effect on regional development}

In the previous sections, we demonstrated how the rise and subsequent decline of Intershop enabled a wave of entrepreneurial activities by former firm members. Through the spin-off activities emerging from Intershop, a substantial number of new software firms were created in its home region. In the present section, we discuss additional effects that Intershop may have had on the development of a regional software industry. Guided by the literature on industrial clusters, we focus on three relevant dimensions: human capital formation, regional cooperation, and the provision of entrepreneurial role models to the broader public.

Intershop's growth strongly increased the pool of software-related human capital in Jena, which, except for a few small companies catering to the technical software needs of the local manufacturing firms, did not have a substantial prior software industry. Intershop's local employment in Jena peaked at some 700 jobs, with the remaining employment largely being divided between San Francisco and Hamburg, where the financial operations were concentrated. Jena has always been the center of product development, and, accordingly, the local Intershop employment was biased toward programmers and software developers. According to Intershop's former director of human resources, most of them came from the broader region. University graduates with degrees in computer science were predominantly hired from the surrounding Technical Universities in Leipzig, Ilmenau, Chemnitz and Dresden.

For the local pool of human capital, capabilities that employees acquired on their jobs at Intershop may have been even more important than the firm's recruitment of computer scientists. As was noted above, the firm hired numerous employees who had no software-related education or job experience, including university students who had not finished their degrees. In this context, the high quality of Intershop's software development was crucial, as it helped to provide a fertile learning environment for acquiring programming skills, particularly in the emerging field of e-commerce software. In line with this conjecture, one spin-off founder characterized Intershop as a "breeder of e-commerce competences."

When Intershop laid off almost 500 employees in Jena, this pool of softwarerelated human capital was accessible not only to its spin-offs, but also to other firms in the region. Our interviewees suggested that indeed many of the employees, particularly those coming from the broader region, attempted to stay in Jena. Official labor market statistics are consistent with this characterization. The number of skilled IT employees ("Datenverarbeitungsfachleute") approximately doubled in Jena from 1994 to 2001 (Fig. 2). ${ }^{5}$ This positive development coincided with the growth of Intershop. In contrast, the subse-

\footnotetext{
${ }^{5}$ With this rate of increase in IT employment, Jena was substantially above the German average in these years.
} 
Fig. 2 IT employees in Jena and the number of intershop employees (source: Institute of employment research (IAB) employment statistics)

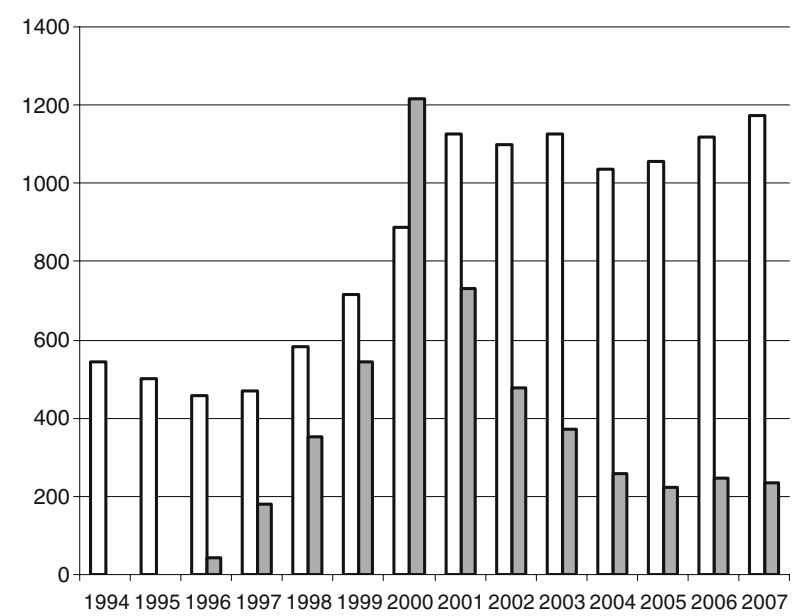

口IT employees in Jena 口Intershop Employees

* Note that not all Intershop employees are classified as IT employees and that they were not all located in Jena.

quent downsizing of Intershop's activities is not reflected in the labor market figures, which largely remained stable after the burst of the dot-com bubble. In addition to the Intershop spin-offs (which between them have created more than 300 jobs locally), former Intershop employees found new employment in existing firms outside the IT sector, and also in new software startups, including those member firms of the TowerByte cooperative that are not Intershop spin-offs.

There is growing evidence indicating that the availability of human capital and the emerging local software industry induces existing firms to move to the region. T-Systems MMS, a multimedia service subsidiary of Deutsche Telekom, opened a branch office in Jena, which hired a number of former Intershop employees and is led by an ex-Intershop manager. T-Systems MMS cooperates with Intershop and several of its spin-offs; it is the German distribution partner of Demandware. In a similar way, Nexum AG, an online marketing consulting firm located in Cologne, has opened an office in Jena. Ifolor, an online photo service from Switzerland, chose Jena as the location of its German subsidiary and hired a former Snapfish manager to head it.

Theories of regional industry agglomeration also emphasize the role of knowledge spillovers and cooperation in local networks. Our interviews suggest that during its growth, Intershop was not connected well in the region. Several interviewees characterized Intershop as a less-than-ideal partner for cooperation. Given its ambitious objectives, the firm shunned potential partners from the region, including the local university, in favor of interregional and international cooperation partners. It was also suggested that Intershop's corporate culture was ill-suited for cooperating with public research. This is consistent with Intershop's failed attempt to endow a chair for e-commerce at the local university, which was intended to form the nucleus of a new program 
in economics and computer science (Uni-Journal Jena, June 2000). This failure was not only caused by the lack of funds after the burst of the dot-com bubble, but also by a "clash of cultures" between the firm's management and the regulations governing the university's appointments. Apparently, Intershop became more open toward regional cooperation only when its crisis had already set in. Interviewees nonetheless suggested that, at present, the Intershop spin-offs are more relevant as cooperation partners than the parent firm itself.

Finally, it is conceivable that the temporary success of Intershop influenced general attitudes toward entrepreneurship in the region and the ensuing willingness to start firms, as its founders may have provided positive role models for potential entrepreneurs (Fornahl 2007). Consistent with this conjecture, in a series of expert interviews on entrepreneurship in Jena conducted in 2001, 14 out of 24 experts mentioned Schambach as an individual who affected local entrepreneurial activities. Evidence supporting the notion that the regional entrepreneurial climate influenced firm formation also emerged from a survey of 93 founders or managers of local startups organized between 1990 and 2001 (ibid., pp. 195-211). Two-thirds of the respondents confirmed that a positive entrepreneurial climate had been a relevant factor in their decision to start a firm. In addition, one-third of the firm representatives answered that earlier regional founders had positively influenced them. ${ }^{6}$ In contrast to these self-reports, however, no quantifiable effect of Intershop's example on subsequent firm formation in Jena was found in the survey. Neither positive founding decisions nor the actual formation of startups were correlated with the respondents' ex-post assessment of the regional entrepreneurial climate at the respective time (ibid.). ${ }^{7}$

\section{Discussion: Intershop and its spin-offs}

Our empirical analysis focused on the entrepreneurial activities of Intershop's founders and employees. In the present section, we discuss the findings from the case study in the context of the prior work on spin-offs and spin-off-based regional clustering.

What lessons about the spin-off process can we derive from the Intershop case? In line with prior literature, the business models of the Intershop spin-

\footnotetext{
${ }^{6}$ No respondent indicated a negative impact of earlier firm formation. This asymmetry may reflect sample bias due to the restriction to firms that were actually started.

${ }^{7}$ There exists, however, a rather illustrative piece of anecdotal evidence for Intershop's effect as a regional role model. A short-lived software firm named Exquisit Technologies was started in Jena in 2000. It focused on speech recognition software, and its founders explicitly acknowledged Intershop as a role model (Financial Times Deutschland, October 17, 2000). In addition, the firm's name itself indicates the Intershop influence. To see this, one needs to know that the name Intershop not only alludes to "internet" and "shopping," but was also the name of the chain of state-run shops that sold Western merchandise (for Western currency) in socialist East Germany. Likewise, Exquisit was the name of shops that sold the highest-quality goods available for Eastern currency.
} 
offs show that their founders made use of specific experiences and knowledge accumulated while working for Intershop. This impression was confirmed in the interviews. An additional aspect is that those founders who were closest to Intershop's strategic decision making (in particular the founders themselves) started the firms the activities of which are closest to the parent firm's markets. Adding to recent findings linking the success of spin-offs to their founders' positions at the parent firm (Dahl and Reichstein 2006), our study therefore indicates that differences in position at the parent firm not only affect the quality of the acquired knowledge, but also its nature and the relative importance assigned to various kinds of experiences and capabilities. The business models of the Intershop spin-offs are furthermore informative with regard to the parent-spin-off relationship. Since, depending on their position, employees acquire specific and in part idiosyncratic capabilities, their entrepreneurial strategies will often differ from the parent firm's business model, thus limiting the extent to which they become its competitors.

It also emerged from the interviews that the general experience of working in a fast-growing, entrepreneurial startup was highly valuable for the subsequent spin-off activities. The spin-off founders' emphasis on the importance of having learned how to run large-scale projects and lead teams resonates with the notion of an "entrepreneurial career imprint," which has been proposed to explain why a large number of managers hired to lead young startups in the emerging U.S. biotech industry came from a single medical products company, Baxter International (Higgins 2005). According to this account, Baxter was similar to Intershop in that it assigned challenging and highly autonomous jobs to its junior executives. They were thus put in a good position to acquire the skills needed to run startup firms. However, while the "Baxter Boys" joined existing young firms, the founders of Intershop's spin-offs started new firms themselves. $^{8}$

Prima facie, the Intershop case is less easily reconciled with the "success breeds success" dynamics characterizing the spin-off process, where better incumbents tend to have more and better spin-offs. There are several ways, however, to account for the large number of Intershop spin-offs in spite of the weak performance of the parent firm, which essentially has been struggling for survival since 2001.

To begin with, Intershop's crisis may have induced employees to form spinoffs that would not have considered entrepreneurial activities under more favorable employment conditions. In the classification proposed by Buenstorf (2007b), many of Intershop's spin-offs were "necessity" rather than "opportunity" spin-offs, because the primary impetus for their formation was the

\footnotetext{
${ }^{8}$ The finding that young firms tend to have more spin-offs than older, more bureaucratic firms (Gompers et al. 2005) is also consistent with our results.
} 
deterioration of career prospects in the parent firm (combined with a shortage of alternative employment options in the region). This holds particularly for those employees who started new ventures out of the transfer firm that Intershop initiated during its downsizing. In this context, it is notable that, in contrast to the theory proposed by Klepper and Thompson (2006), several interviewees discounted the role of strategic disagreements as a factor in their spin-off decision. Given Intershop's precarious situation after 2000, necessitybased spin-off activities apparently did not require conflicts as further triggers. At the same time, strategic disagreements were crucial for two of the three ventures started by Intershop's founders, ePages and Demandware. The latter case shows that even the founder/CEO of an established firm may be unable to pursue a radically new strategy within the existing organization.

On a related note, Intershop was a pioneering early entrant into ecommerce software development, and its products were highly regarded for their quality. The firm thus seems to accord to the account of spin-off generation given by Agarwal et al. (2004). Technological capabilities were developed in the firm, but given its fragile situation after 2001, Intershop was unable to exploit the ensuing opportunities, thus creating a potential for employees to start spin-offs. Since it had little prospect of broadening the range of its activities, these spin-offs - except when entering into the core e-commerce market itself - did not threaten to become competitors of the parent firm. Intershop could therefore "afford" to support their emergence, as is indicated by its sponsoring of the transfer firm that evolved into the TowerByte cooperative.

Finally, specific characteristics of the software industry, both in terms of its life cycle and in terms of product design, may have added to the propensity of spin-off formation in the Intershop case. Because of the sudden end of the dot-com boom, with Intershop, a firm was downsizing that belonged to the technological vanguard in a young industry with low barriers to entry. This contrasts with the frequent pattern that the decline or exit of industry incumbents is part of a more general industry shakeout. In the latter situation, there are much fewer opportunities for starting successful spin-offs.

Software is moreover a prime example of heterogeneous and modular product design. In the laser industry, which is also characterized by heterogeneous submarkets, specialization along submarkets has been found to favor spinoff entry (Klepper and Sleeper 2005; Buenstorf 2007a). The same seems to hold for the software industry. Product modularity is likewise favorable to the formation of spin-offs, in particular since modularity was a significant aspect of the alleged quality of Intershop's software products. Modularity is relevant for the spin-off process, as it allows for entry by horizontal or vertical disintegration, i.e. specialization on some specific aspect of the software product or its development.

How did the entrepreneurial activities of Intershop's founders and employees affect the firm's home region? Most spin-offs entered at the location where their founders had been active. As Intershop had established various regional branch offices, this was not always Jena, but still roughly two-thirds of the new 
firms (25) located in Jena and another four entered within a 100-km range. This conforms to the oft-observed pattern that entrepreneurs stay in their home region when starting a new firm (Cooper and Folta 2000; Fornahl and Graf 2003).

The local entrants created new jobs, thus helping to retain in the region a substantial fraction of the software-related human capital that had been brought in and/or bred by Intershop. Between the parent firm and the spin-offs, the current number of jobs amounts to about three-quarters of Intershop's peak local employment. In fact, even though Jena remains a high-unemployment region, our interviewees suggested that their firms' future growth prospects may be limited by a shortage of trained software developers.

However, Demandware, the most ambitious of the Intershop spin-offs, located far from its geographical roots. Demandware's direct effects are probably detrimental to the region, because the firm is a competitor of Intershop as well as ePages, and also attracted human capital away from Jena. At the same time, the firm cooperates with some of Intershop's employee spin-offs, which may give rise to some positive indirect effects on the region.

The tendency of spin-offs to locate in their home region is a key component of the spin-off-based account of cluster formation (Klepper 2007, 2008; Buenstorf and Klepper 2008). The present analysis confirms this tendency for the Intershop case. More importantly, our findings provide further clues for understanding how spin-offs shape regional industrial dynamics. Because of the differences in their on-the-job-learning experiences, the ventures started by the different spin-off founders also differ in their business models and strategies. As a consequence, they are generally not competing for the same customers, but often offer vertically or horizontally related products and services. Combined with the shared experience of having worked in the same firm, and the ensuing familiarity with each other's strengths and weaknesses, spin-off founders have access to a localized network of capabilities, skills, and financial capital that they can employ to mutual benefit.

Indeed, while our interviewees dismissed the importance of Intershop's regional cooperation, the importance of the network of spin-off firms was frequently stressed, both within the TowerByte cooperative and beyond. Furthermore, the presence of several employers specializing in similar segments of the software industry reduces the hazard of job losses for potential employees. The interactions between spin-offs thus seem to conform closely to the conventional theories of Marshallian agglomeration economies stressing knowledge spillovers, labor pooling and vertical relationships within clusters.

In this case, at least, the spin-off process seems to have been the key to cluster emergence, providing the foundation on which performance-enhancing interactions between firms could develop. Thus, the self-augmenting character of the spin-off process is further reinforced by increasingly powerful external effects of agglomeration. To the extent they are mediated by network membership, the benefits of these external effects would be restricted to former 
Intershop employees and their entrepreneurial activities. Interestingly, though, with the TowerByte cooperative, an institutional framework was established that enhances the accessibility of localized knowledge and other benefits, extending it to startups whose founding context was unrelated to Intershop.

\section{Conclusion: from dot-com to regional software industry}

From an investor's point of view, Intershop, similar to many other dot-com firms, was a bad long-term investment. Our objective in the present article was to qualify this assessment by adopting a regional perspective and tracing Intershop's regional legacy 7 years after the end of the dot-com boom. We identified key elements of the spin-off-based account of cluster formation in the Intershop case. Intershop was an early entrant into e-commerce software, and there were no systematic reasons other than the founders' biographies why it emerged in Jena and not elsewhere. Intershop's growth attracted human capital to the region and enabled employee learning. Subsequent spin-off formation by the Intershop founders and other employees spawned a substantial number of additional entrants. The characteristics of the new firms suggest that founders were able to transfer relevant knowledge they acquired at Intershop. Intershop even actively supported new entry by spin-offs. It thus helped to create conditions that were conducive to the emergence of an industry cluster. The spin-offs stabilized and further enhanced these conditions by establishing a network of local cooperation on the basis of their founders' shared Intershop background. Spin-off interaction gave rise to Marshallian agglomeration economies in the network. Moreover, with the TowerByte cooperative, an institutional setup was created that allows non-spin-off startups to partake in the benefits accruing from the network.

Through these developments, Intershop became the nucleus of a software industry cluster focusing on e-commerce activities, which is becoming increasingly independent of the parent firm's development. It is obviously impossible to predict whether the cluster will eventually grow beyond the employment level that Intershop had reached at height of its success. At present, however, both quantitative trends and qualitative dynamics suggest a further favorable cluster development.

The Intershop case shows how a temporarily successful dot-com firm exerted a lasting beneficial effect on regional development-which might even outlive the original firm. A general conclusion can thus be drawn that resonates with the recent work on serial entrepreneurship. In assessing the merits of entrepreneurial activities, not only the fate of the individual firm has to be taken into account, but also learning effects that condition the performance of future ventures started by the initial entrepreneur as well as other members of the firm. A straightforward policy corollary is that, in regions faced with the decline of individual firms, stabilizing policy interventions may target 
entrepreneurial activities out of the declining firms rather than trying to support these firms themselves. ${ }^{9}$ In this context, industry (life cycle) characteristics affecting the viability of spin-off activities warrant close scrutiny.

The case study moreover highlights the need for policy makers to remain open to unforeseeable, spontaneous regional developments. Prior to Intershop, Jena was not likely to become a center of the software industry. The emergence of the fledgling industry was not (and probably could not have been) based on any deliberate policy initiative. In contrast, the spin-off activities out of Intershop were supported by private initiatives such as the TowerByte and TowerVenture cooperatives. These might serve as models for similar organizations elsewhere, allowing regional policy makers to restrict themselves to providing favorable conditions and possibly inducements for such private initiatives instead of establishing public entities.

Even though there are many differences in the details, the general finding that Intershop enabled further entrepreneurship and industry growth in its home region is in line with experiences made elsewhere. Our account of the spin-off dynamics in Jena resonates with Helft's (2006) account of how, after PayPal was acquired by eBay, numerous new firms, including YouTube and LinkedIn, were started by PayPal's founders and employees. Outside of Silicon Valley, spin-off activities emerging from Microsoft and Amazon in and around Seattle have been noted (Markoff 2008). The developments triggered by Pittsburgh-based FreeMarkets Inc. are even more similar to the Intershop case because they took place in a region that is not known as a center of the software industry. FreeMarkets, which organized B2B online auctions, experienced a similarly spectacular decline in value as did Intershop and was acquired in 2004. FreeMarket's founder and its former COO started an investment company that provided funding to several regional software businesses. Two of them (Tiversa, SEEC) are led by former FreeMarkets executives. In addition, spin-off activities by individual FreeMarkets employees can also be observed.

Our overall conclusion from this study is that a qualification to the ex post assessment of the dot-com boom seems justified. Not all of the money spent by the dot-coms has been wasted, but capabilities have been created that may allow for more sustainable growth and performance of the surviving firms and the second-generation entrants. The spin-off process is crucial as a transfer mechanism for these capabilities. Given the tendency of spin-offs to locate close to their geographical roots, it allows for regional clusters to evolve out of temporary developments such as the dot-com bubble.

\footnotetext{
${ }^{9}$ This is in line with the more general suggestion in Buenstorf (2007b) that necessity spin-offs may be socially beneficial because of their ability to limit the devaluation of industry-specific human capital.
} 
Open Access This article is distributed under the terms of the Creative Commons Attribution Noncommercial License which permits any noncommercial use, distribution, and reproduction in any medium, provided the original author(s) and source are credited.

\section{References}

Agarwal R, Echambadi R, Franco AM, Sarkar MB (2004) Knowledge transfer through inheritance: spin-out generation, development and survival. Acad Manage J 47:501-522

Audretsch DB, Feldman MP (1996) R\&D spillovers and the geography of innovation and production. Am Econ Rev 86:630-640

Berberich F (1999) E-commerce aus Jena. Die Welt, 16 September

Brenner T (2004) Local industrial clusters. Existence, emergence and evolution. Routledge, London

Bresnahan T, Gambardella A, Saxenian A (2001) Old economy' inputs for 'new economy' outcomes: cluster formation in the new silicon valleys. Ind Corp Change 10:835-860

Brittain JW, Freeman J (1986) Entrepreneurship in the semiconductor industry. Mimeo

Buenstorf G (2007a) Evolution on the shoulders of giants: entrepreneurship and firm survival in the German laser industry. Rev Ind Organ 30:179-202

Buenstorf G (2007b) Opportunity spin-offs and necessity spin-offs. Max Planck Institute of Economics, Papers on Economics and Evolution \#0718

Buenstorf G, Klepper S (2006) Why does entry cluster geographically? Evidence from the U.S. tire industry. Mimeo

Buenstorf G, Klepper S (2008) Heritage and agglomeration: the Akron tyre cluster revisited. Econ $\mathrm{J}$ (in press)

Clemens S (2006) Untypisch erfolgreich. Ostthueringer Zeitung, 12 December

Cooper A, Folta T (2000) Entrepreneurship and hightechnology clusters. In: Sexton DL, Landström H (eds) The Blackwell handbook of entrepreneurship. Blackwell Business, Malden, pp 348-367

Dahl MS, Pedersen CØR, Dalum B (2003) Entry by spinoff in a high-tech cluster. DRUID Working Paper 2003-11

Dahl MS, Reichstein T (2006) Heritage and survival of spin-offs: quality of parents and parenttenure of founders. Mimeo

Deutsche Schutzvereinigung für Wertpapierbesitz (2006) Press release: DSW Watchlist 2006, 16 February

Echikson W (2000) Germany's hot star-intershop eyes the big leagues for its e.biz software. BusinessWeek Online, 7 February

Eisenhardt KM (1989) Building theories from case study research. Acad Manage Rev 14:532-550

Eriksson T, Kuhn JM (2006) Firm spin-offs in Denmark 1981-2000-patterns of entry and exit. Int J Ind Organ 24:1021-1040

Feldman MP (2001) The entrepreneurial event revisited: firm formation in a regional context. Ind Corp Change 10:861-891

Fornahl D (2003) Entrepreneurial activities in a regional context. In: Fornahl D, Brenner T (eds) Cooperation, networks and institutions in regional innovation systems. Edward Elgar, Cheltenham, pp 38-57

Fornahl D (2007) Changes in regional firm founding activities-a theoretical explanation and empirical evidence. Routledge, London

Fornahl D, Graf H (2003) Standortfaktoren und Gründungsaktivitäten in Jena. In: Cantner U, Helm R, Meckl R (eds) Strukturen und Strategien in einem Innovationssystem - das Beispiel Jena. Verlag Wissenschaft und Praxis, Stuttgart, pp 97-123

Fritsch M (2004) Entrepreneurship, entry and performance of new business compared in two growth regimes: East and West Germany. J Evol Econ 14:525-542

Garvin DA (1983) Spin-offs and the new firm formation process. Calif Manage Rev 25:3-20 
Gompers P, Lerner J, Scharfstein D (2005) Entrepreneurial spawning: public corporations and the genesis of new ventures, 1986 to 1999. J Finance 60:577-614

Gray M, Golob E, Markusen A (1996) Big firms, long arms, wide shoulders: the 'hub-and-spoke' industrial district in the Seattle region. Reg Stud 30:651-666

Helft M (2006) It pays to have pals in Silicon valley. New York Times, 17 October

Higgins M (2005) Career imprints. Creating leaders across an industry. Josey-Bass, San Francisco

Kalla F (2005) TowerByte eG will weiter wachsen. Ostthueringer Zeitung, 28 June

Klawitter N (2003) Ich habe richtigen Druck. Der Spiegel, 21 July

Klepper S (2002) The capabilities of new firms and the evolution of the US automobile industry. Ind Corp Change 11:645-666

Klepper S (2007) Disagreements, spinoffs, and the evolution of Detroit as the capital of the U.S. automobile industry. Manage Sci 53:616-631

Klepper S (2008) Silicon valley: a chip off the old detroit bloc. In: Audretsch DB, Strom R (eds) Entrepreneurship, growth, and public policy. Cambridge University Press, Cambridge UK (in press)

Klepper S, Sleeper SD (2005) Entry by spinoffs. Manage Sci 51:1291-1306

Klepper S, Thompson P (2006) Intra-industry spinoffs. Mimeo

Lawson C (2003) Technical consultancies and regional competences. In: Dannreuther C, Dolfsma W (eds) Globalisation, inequality and social capital. Contested concepts, contested experiences. Edward Elgar, Cheltenham, pp 75-92

Lundvall $\mathrm{BA}$ (1988) Innovation as an interactive process-from user-producer interaction to national systems of innovation. In: Dosi G, Freeman C, Nelson R, Silverberg G, Soete L (eds) Technology and economic theory. Pinter, London, pp 349-369

Markoff J (2008) Seattle taps its inner Silicon Valley. New York Times, 8 February

Moore G, Davis K (2004) Learning the Silicon Valley way. In: Bresnahan T, Gambardella A (eds) Building high-tech clusters: Silicon Valley and beyond. Cambridge University Press, Cambridge

Patrucco PP (2005) The emergence of technology systems: knowledge production and distribution in the case of Emilian plastics district. Camb J Econ 29:37-56

Querengaesser R (2004) Intershop-Turm ist auch eine große Digitalfoto-Schleuse. Ostthueringer Zeitung, 3 November

Sarasvathy SD, Menon AD (2004) Failing firms and successful entrepreneurs: serial entrepreneurship as a temporal portfolio. Darden working paper series \# 04-05, University of Virginia

Schoenberger E (1981) The corporate interview as a research method in economic geography. Prof Geogr 43:180-189

Shane S (2000) Prior knowledge and the discovery of entrepreneurial opportunities. Organ Sci 11:448-469

Sorenson O (2003) Social networks and industrial geography. J Evol Econ 12:513-527

Sørensen JB, Sorenson O (2003) From conception to birth: opportunity perception and resource mobilization in entrepreneurship. Adv Strateg Manage 20:71-99

Toparkus K (2004) Epages meldet schwarze Zahlen aus dem Intershop-Tower. Ostthueringer Zeitung, 25 February

Virtel M (2001) Wenn ein Wunderkind Papiergeld verliert. In: Hebestreit M, Gowers A (eds) 101 Köpfe der New Economy. Financial Times Prentice Hall, London, pp 199-201

Von Bredow R, Jung A (2001) Absturz eines Internet-Stars. Der Spiegel, 8 January

Westhead P, Wright M (1998) Novice, portfolio, and serial founders: are they different? J Bus Venturing 13:173-204 